\title{
New record of lithic blades in Brazil: The Picão site, São Paulo state
}

\author{
Nicolás Batalla, Letícia C. Correa, Astolfo G. M. Araujo
}

Laboratório Interdisciplinar de Pesquisas em Evolução, Cultura e Meio Ambiente, Museu de Arqueologia e Etnologia (MAE), Universidade de São Paulo. Av. Prof. Almeida Prado, 1466, CEP 05508-070, São Paulo, SP,

Brazil. Email: Batalla: arnico.batalla@usp.br; Correa: leticiacorrea@usp.br; Araujo: astwolfo@usp.br

\begin{abstract}
:
Lithic blades are long and narrow flakes produced from prepared cores which form part of different technological complexes all around the world. In South America, the production and use of blades has been reported in different settings which include early hunter-gatherer occupations of the Pleistocene-Holocene transition, as well as Middle and Late Holocene occupations. Until now, the only reference to blade technology in Brazil comes from the south and corresponds to Early Holocene hunter-gatherer assemblages. This paper presents a second record of lithic blades in Brazil, which includes one fragment and three refitted artifacts manufactured from fine-grained silicified sandstone recovered from a surface site (Picão), which is located in the Dourado Municipality, central São Paulo state. Analysis undertaken on the blades involved the collection of metric data, including longitudinal curvature, and the elaboration of diacritic schemes which consider the direction and order of the observed remnant scars for interpreting the chronological sequence of removals. Results indicate the production of $\geq 70.5 \mathrm{~mm}$-long, softly curved blades, with evidence of preparation of the point of impact prior to extraction from the core, as well as the presence of unidirectional, parallel scars related to blade production from a single striking platform. These reduction characteristics resemble those encountered in the nearest contexts of southern Brazil and northern Uruguay, although differences also exist. In spite of the lack of chronological data, this new record of blades in central São Paulo state calls for more research into the origins and dispersion of this technology in southeastern South America.
\end{abstract}

Keywords: lithic blade technology; reduction sequence; diacritic analysis; São Paulo state; southeastern Brazil

\section{Introduction}

Lithic blade technology constitutes an integral part of different archaeological contexts and periods all around the world, including the Americas. In North America blades are a significant component of various early archaeological complexes and technological traditions. Blades and blade cores are a well-known marker of the Clovis complex or culture ( $\mathrm{ca}$. 13,125-12,925 cal BP, according to the minimum range of Waters \& Stafford 2007: 1123), and they have been intensely studied and characterized (e.g., Beck \& Jones 2015; Boldurian

Published by the School of History, Classics and Archaeology, University of Edinburgh ISSN: 2055-0472. URL: http://journals.ed.ac.uk/lithicstudies/ 
\& Hoffman 2009; Bradley et al. 2010: 10-55; Collins 1999; Collins \& Lohse 2004; Sain 2012). Some pre-Clovis technological complexes in North America also include blades (Adovasio \& Pedler 2004). The obsidian blades produced by pressure flaking in Mesoamerica are perhaps among the most well-known of the continent (see review in Hirth 2012).

In this paper, blades are defined as long and narrow flakes that exhibit specific attributes such as sub-parallel to parallel sides, which are detached from prepared cores intentionally made for that purpose (Bradley et al. 2010: 10; Collins 1999; Inizan et al. 1995: 73). Considerable variation in blade core preparation, blank production and blade tool uses is recognized around the world (e.g., Bar-Yosef \& Kuhn 1999; Boëda 1988).

\subsection{Blade technology in South America and Brazil}

There are several studies which report blade-making technology in South America, and these comprise different time periods, preparation and production methods and functional uses. Several blades and blade cores have been found in archaeological components ranging from the Late Pleistocene to the Early Holocene, and thus were part of the toolkits of the Paleoindians, or first inhabitants of the sub-continent.

In northern Uruguay, along the frontier with Brazil, blades and a blade core were recognized in component 1 of the Pay Paso 1 site by Suárez (2011a: 127-131, 133-134; 2011b: 367-372) in dated levels ca. 10,900-10,630 BP (12,800-12,700 cal BP, according to Suárez 2015:93). Other blades, retouched blades and a blade core were recovered from a further Paleoindian component of this site, dated to between $c a .12,000$ and 11,400 cal BP (see Suárez 2011a: 141-142, fig. 6.15; 2011b: 371-372; 2015). More recently, Suárez et al. (2017 in press) reported three blades excavated in the Tigre site, located on the Middle Uruguay river bank, in a $c a$. 11,750-11,090 cal BP-dated stratigraphic unit. To this excavated evidence can be added surface finds in Uruguay (e.g., Hilbert 1991; Suárez 2015: fig.5; Taddei 1980), which include blade tools recovered together with diagnostic Paleoindian artifacts (Nami 2013: 13; Suárez et al. 2018).

In southern Argentina, in the Patagonian region, blades and retouched blades were recovered in the Cerro Tres Tetas locality (Santa Cruz plateau) in levels dating back to $c a$. 11,500-10,200 BP (Paunero 2003: 136) and in the Casa del Minero 1 site since at least $c a$. 11,000 BP up to the Late Holocene (e.g., Skarbun et al. 2007: 595, fig. 5).

Lithic blades have also been registered in Middle Holocene human occupations in South America. In the northern coast of Peru, at the Paredones site, a blade made of andesite was found in deposit dated to $c a$. 6,775-6,504 cal BP that exhibited microscopic use-wear from the processing of vegetables, as well as starch grains from maize along its edges, in a context with close association with maize cobs (Dillehay \& Bonavia 2017: 438, fig. 11.2; Grobman et al. 2012).

In Argentina, blade technology for the Middle Holocene period has been recognized in different regions. The arid highland plateau (puna) of northwestern Argentina presents blades among its lithic assemblages since at least $c a$. 9,600-8,300 BP (Restifo 2015), although a technology strictly oriented towards the production of blades from prepared cores is only evidenced by the end of the Middle Holocene (Restifo \& Hoguin 2012; Restifo 2015).

In Argentinean Patagonia, blades and tools made on blade blanks are represented among the lithic assemblages recovered in the Los Toldos locality making up part of the Casapedrense industry, which was defined by Menghin (1952) and dated ca. 7,260 BP (Cardich et al. 1973) (see review in Hermo \& Magnin 2012). Blades and blade tools are also recognized in southwestern Patagonia between ca. 5,000 and 2,500 (Aschero et al. 1993) and in central-northern Patagonia in contexts dating between ca. 5,080 and 3,350 BP (Nami \& Bellelli 1994). The role of blade technology in Middle Holocene contexts in Patagonia ( $c a$. 
7,500-3,500 BP) was recently highlighted by Hermo \& Magnin (2012; see also Hermo \& Lynch 2015), who synthesized and analyzed samples from excavated and surface findings from the Deseado massif. In the same region, microscopic use wear analysis carried out on blades and blade tools (retouched flakes and scrapers) from $c a$. 7,700-3,200 BP stratigraphic units of Maripe Cave, revealed microtraces of cutting and scraping bones and soft animal material as well as traces of scraping hard vegetal material (Lynch \& Hermo 2017).

Until now, the only reference to lithic blades in Brazil was reported in the south by Hoeltz et al. (2015) and Lourdeau et al. (2014; 2017). Working in three different archaeological sites from the Foz do Chapecó region (eastern Santa Catarina and northwestern Rio Grande do Sul states), Lourdeau et al. (2014) detected and analyzed a total of 101 blades, with associated dates ranging from $c a$. 8,370 to 6990 BP. More blades were recently reported in excavated units dating back to the Early Holocene in sites from the same region, and five blade cores were reported as surface finds while conducting an archaeological survey (Lourdeau et al. 2017).

This paper provides new evidence for lithic blade technology in South America by reporting and characterizing artifacts collected in a survey in the Dourado region, in the geographic center of São Paulo state, southeastern Brazil (see Figure 1).

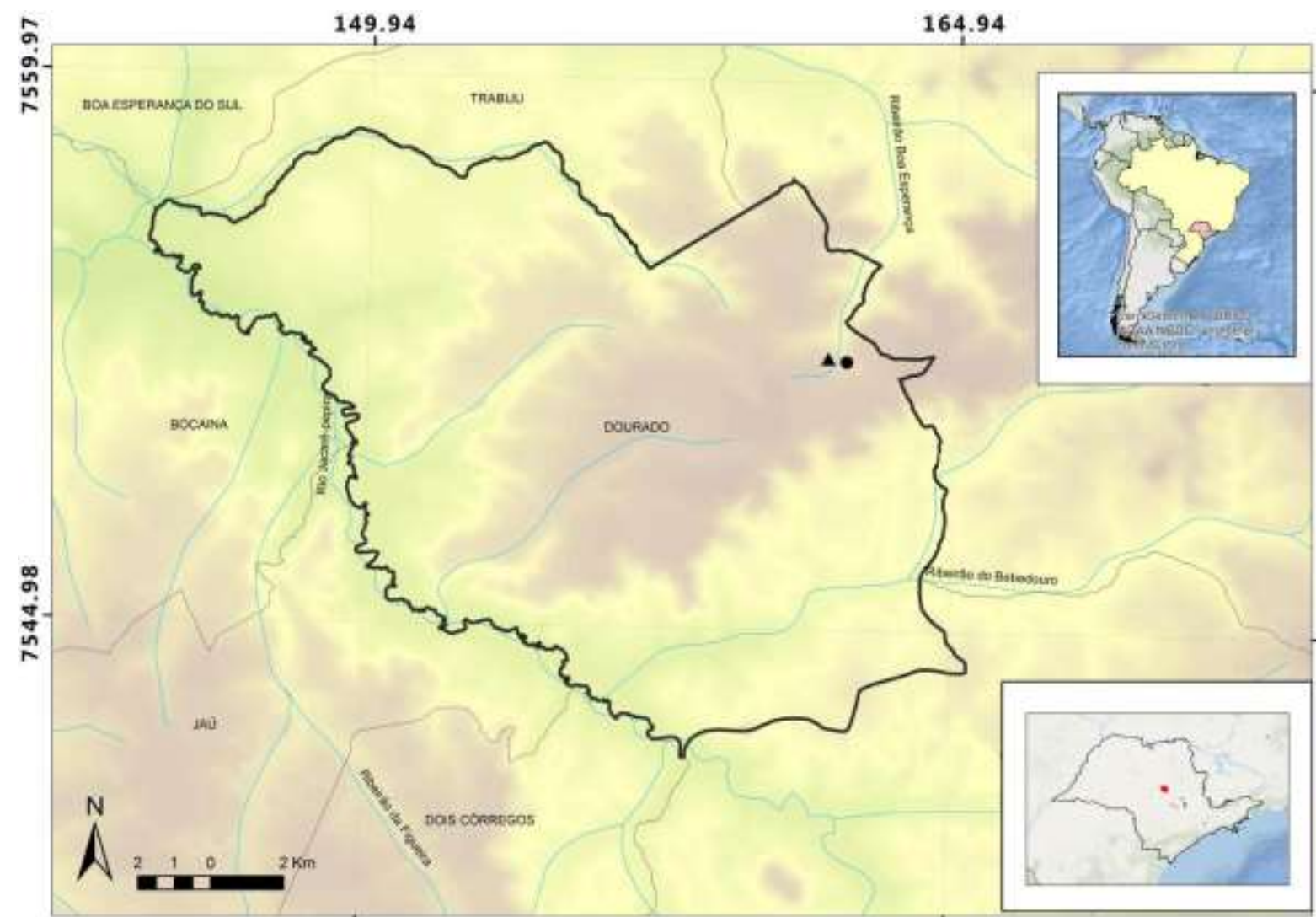

Figure 1. Location of the sites mentioned in the text, within Dourado Municipality, central São Paulo state, southeastern Brazil. Black triangle: Picão site; Black circle: Bastos site. Coordinates are in UTM.

\subsection{Archaeological and geological setting}

The Picão site, where the blades reported here were collected, was detected while conducting a survey in December 2016 that aimed to locate lithic raw material sources used by hunter-gatherers inhabiting the Dourado Municipality area (Figure 1). In the central São Paulo region, long recognized for its diverse lithic assemblages and significance for understanding the peopling of South America (e.g., Araujo 2001a; Beltrão 1974), new 
research is being conducted based at São Paulo University that has reported (among other finds) evidence of hunter-gatherer occupations between $c a$. 12,640 and 7,650 cal. BP at the Bastos site (Araujo \& Correa 2016). The antiquity of the Bastos site posits it as the earliest known Paleoindian site in São Paulo state, where other early sites have also been recently reported (Araujo et al. 2017; Santos 2011; Troncoso et al. 2016).

The Picão site (central UTM point: 22K 0780795 / 7553549) consists of a surface lithic scatter $0.48 \mathrm{~km}$ away from the Bastos site which extends for a maximum of $56.5 \mathrm{~m}$ and is located $680 \mathrm{~m}$ above sea-level. The site is located in a sugarcane plantation (which characterizes the regional agricultural landscape), with artifacts found within and between the cropped areas, the latter including paths inside the plantation (Figure 2). Artifacts collected add up to 36 specimens, including six flakes, eleven broken flakes, ten flake fragments, two retouched flakes, one broken blade and six blade fragments. The blades and blade fragments were found in the same square meter, suggesting a very good spatial resolution for the site, in spite of the plowing activity (see Araujo 2001b; Lewarch \& O’Brien 1981). No cores were detected.

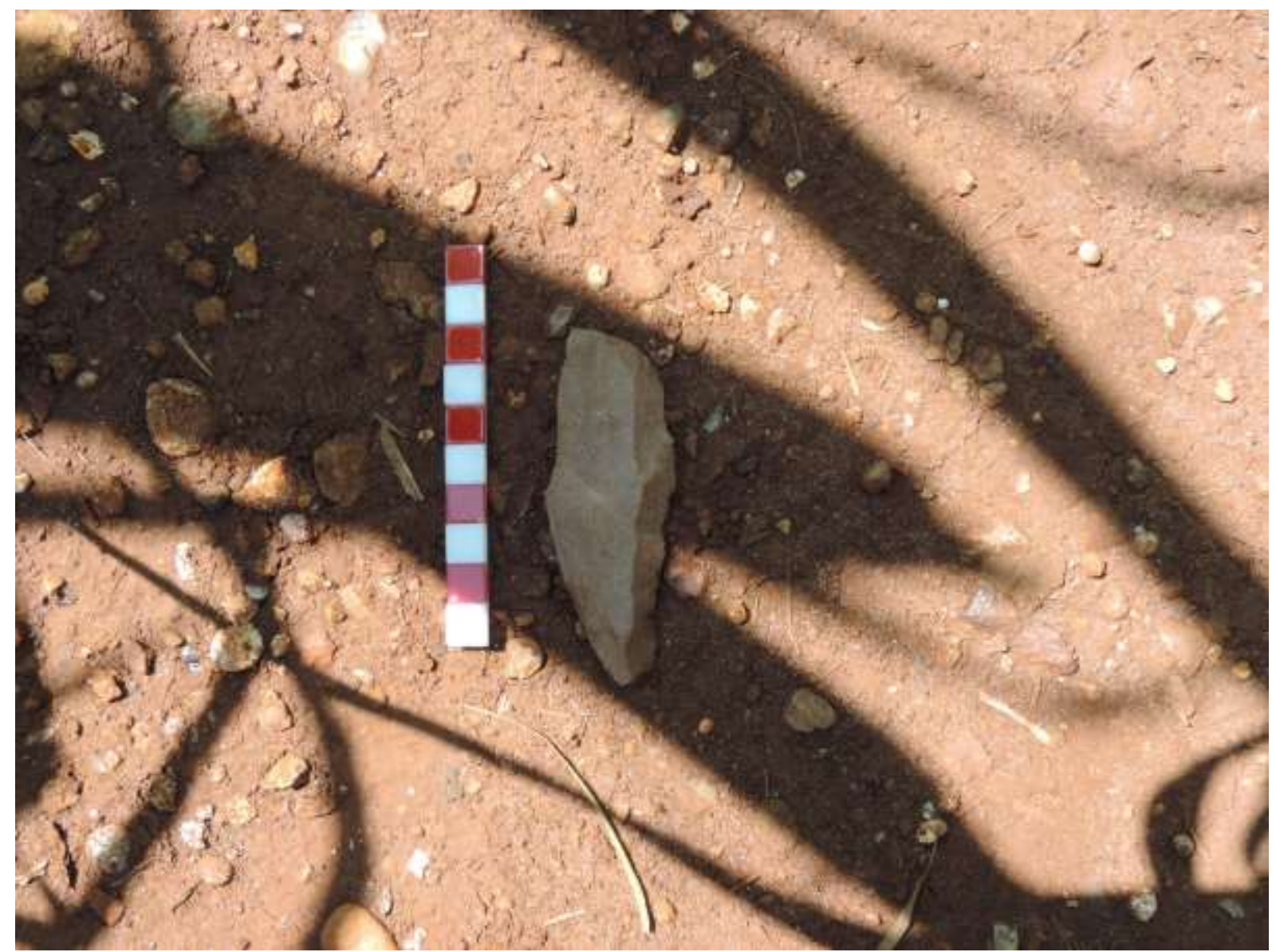

Figure 2. Lithic blade detected on the surface of a path within a sugarcane plantation, Picão site.

The regional landscape is characterized by hills with flat tops composed of Lower Cretaceous basaltic rocks of the Serra Geral Formation and several sandstone packages that are the result of the development of different depositional systems since the Upper PermianEarly Triassic (IPT 1981; Lopes et al. 2004). The Picão site is located on an upper slope terrace surrounded by several silicified sandstone outcrops, most of which consist of knappable raw material primary sources which are currently under analysis. All of the 
artifacts collected in the Picão site, including the blades here analyzed, are manufactured from this rock. No cortex was detected in the blades.

\section{Methods}

The seven specimens collected in the Picão site, including one broken blade and six blade fragments, add up to four artifacts (one fragment and three refitted). Two analytical procedures were followed, according to a complementary view of conceptual approaches to lithic blade technology. Firstly, metric attributes and indices were recorded. Maximum length, maximum width and maximum thickness were measured with a sliding caliper; weight was measured with a digital scale with $0.1 \mathrm{~g}$ precision; edge angle was measured with a digital goniometer. The sum of maximum length, maximum width and maximum thickness was considered, as applied by Bradley et al. (2010: 10-55), Collins (1999) and Collins \& Lohse (2004: 165-176) for Clovis blades, who used it as a general description of overall size. The ratio of each maximum dimension (length, width and thickness) to the summed dimensions was then calculated (see Table 1), following the same authors. The Index of Curvature, developed by Collins (1999: 86) to record one of the distinctive traits of Clovis blades -their longitudinal curvature-was also measured on complete and refitted blades from Picão (as depicted in Figure 3) considering that the greater the value, the more curved the blade. A maximum curvature point in percentage terms, from the proximal to the distal end of the blade, was also estimated following Boldurian \& Hoffman (2009) (Figure 3). These measurements were taken because they provide additional metric data about morphological variation and also because they were applied to blades from neighboring Uruguay (Suárez 2011a, Suárez 2011b).

Table 1. Ratios and indices measured in the blades analyzed from Picão site.

\begin{tabular}{|c|c|c|c|c|c|c|}
\hline Artifact No. & $\begin{array}{l}\text { Length + } \\
\text { Width + } \\
\text { Thickness } \\
(\mathrm{mm})\end{array}$ & $\begin{array}{l}\text { Length/ } \\
\text { Length + } \\
\text { Width + } \\
\text { Thickness } \\
\text { (mm) }\end{array}$ & $\begin{array}{l}\text { Width/ } \\
\text { Length + } \\
\text { Width + } \\
\text { Thickness } \\
\text { (mm) }\end{array}$ & $\begin{array}{c}\text { Thickness/ } \\
\text { Length + } \\
\text { Width + } \\
\text { Thickness } \\
(\mathrm{mm})\end{array}$ & $\begin{array}{l}\text { Index of } \\
\text { Curvature } \\
\text { (ratio) }\end{array}$ & $\begin{array}{l}\text { Maximum } \\
\text { curvature } \\
\text { point (\%) }\end{array}$ \\
\hline PCO023 ${ }^{1}$ & - & - & - & - & 2.24 & 45 \\
\hline PCO024-a & - & - & - & - & - & - \\
\hline PCO024-b & - & - & - & - & $1.33^{2}$ & $52^{2}$ \\
\hline PCO025-a & - & - & - & - & - & - \\
\hline PCO025-b & $154.00^{3}$ & $0.60^{3}$ & $0.29^{3}$ & $0.10^{3}$ & $3.93^{3}$ & $61^{3}$ \\
\hline PCO026-a & - & - & - & - & - & - \\
\hline PCO026- $b^{1}$ & - & - & - & - & $2.17^{4}$ & $46^{4}$ \\
\hline
\end{tabular}

1. Blade fragment, which inhibited the taking of several measurements

2. Estimated in blade refitted with blade fragments (without platforms) PCO024-a and PCO024-b

3. Estimated in blade refitted with broken blade (with platform) PCO025-a and blade fragment (without platform) PCO025-b

4. Estimated in blade refitted with blade fragments (without platforms) PCO026-a and PCO026-b

Secondly, in order to understand the reduction sequence (or chaîne opératoire) by which the blades were produced, a diacritical analysis of each artifact was made according to Dauvois (1976: 194-201). Diacritical analysis considers the direction and order of the observed remnant scars for establishing an interpreted chronological sequence of removals. This method was also used by Lourdeau et al. (2014; see also Hoeltz et al. 2015) for the 
analysis of the blades recovered in southern Brazil, allowing for technological comparison with the geographically-closest blades reported until now.

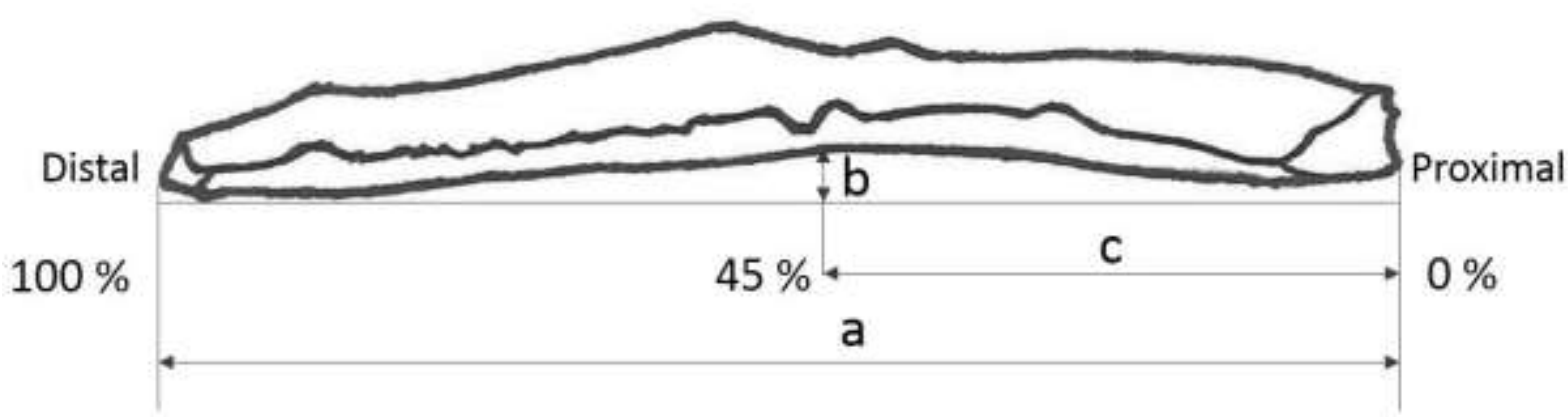

Figure 3. Measures for the calculation of the Index of Curvature ( $a$ and $b$ ) and the blade maximum curvature point (c). The Index of Curvature is calculated as b/a x 100. The maximum curvature point is a percentage estimated from proximal to distal end. Drawing by Nicolás Batalla, based on Boldurian \& Hoffman (2009: fig. 7) and Collins (1999: fig. 7).

\section{Blade analysis results}

The metric dimensions of the blades are presented in Table 2. The largest specimen in terms of length is the blade resulting from refitting fragments PCO024-a and PCO024-b, which is $112.5 \mathrm{~mm}$-long, although given that the proximal end is missing, the total length is not known (see Figure 4).

Table 2. Metric variables recorded in the blades analyzed from Picão site.

\begin{tabular}{lccll}
\hline Artifact No. & $\begin{array}{c}\text { Length }(\mathrm{L}) \\
(\mathrm{mm})\end{array}$ & $\begin{array}{c}\text { Width }(\mathrm{W}) \\
(\mathrm{mm})\end{array}$ & $\begin{array}{c}\text { Thickness }(\mathrm{T}) \\
(\mathrm{mm})\end{array}$ & $\begin{array}{c}\text { Weight }(\mathrm{W}) \\
(\mathrm{g})\end{array}$ \\
\hline PCO023 $^{1}$ & 89.00 & 26.00 & 10.00 & 27.20 \\
PCO024-a $^{1}$ & 67.50 & 46.00 & 12.00 & 42.80 \\
PCO024- $^{1}$ & 45.00 & 42.50 & 9.00 & 25.40 \\
PCO025- $^{2}$ & 39.00 & 45.00 & 16.00 & 25.80 \\
PCO025- $^{1}$ & 54.00 & 35.50 & 9.00 & 22.60 \\
PCO026-a $^{1}$ & 41.00 & 22.50 & 6.50 & 7.40 \\
PCO026- $^{1}$ & 29.50 & 24.50 & 7.00 & 5.90 \\
\hline
\end{tabular}

1. Blade fragment (without platform)

2. Broken blade (with platform)

The highest Index of Curvature value was observed in the blade refitted with blade fragment PCO025-a and broken blade PCO025-b (Table 1). All of the blades are curved to some degree (all values are higher than zero), being that the maximum curvature of the most curved artifact reached beyond the midpoint of the longitudinal profile (Table 1).

To follow up with the technological analysis of the interpreted reduction sequence for the reported artifacts, a general description for each is made and drawings are presented in Figures 4, 5, 6 and 7. The drawings consist of both a conventional technological drawing and a diacritical scheme. 

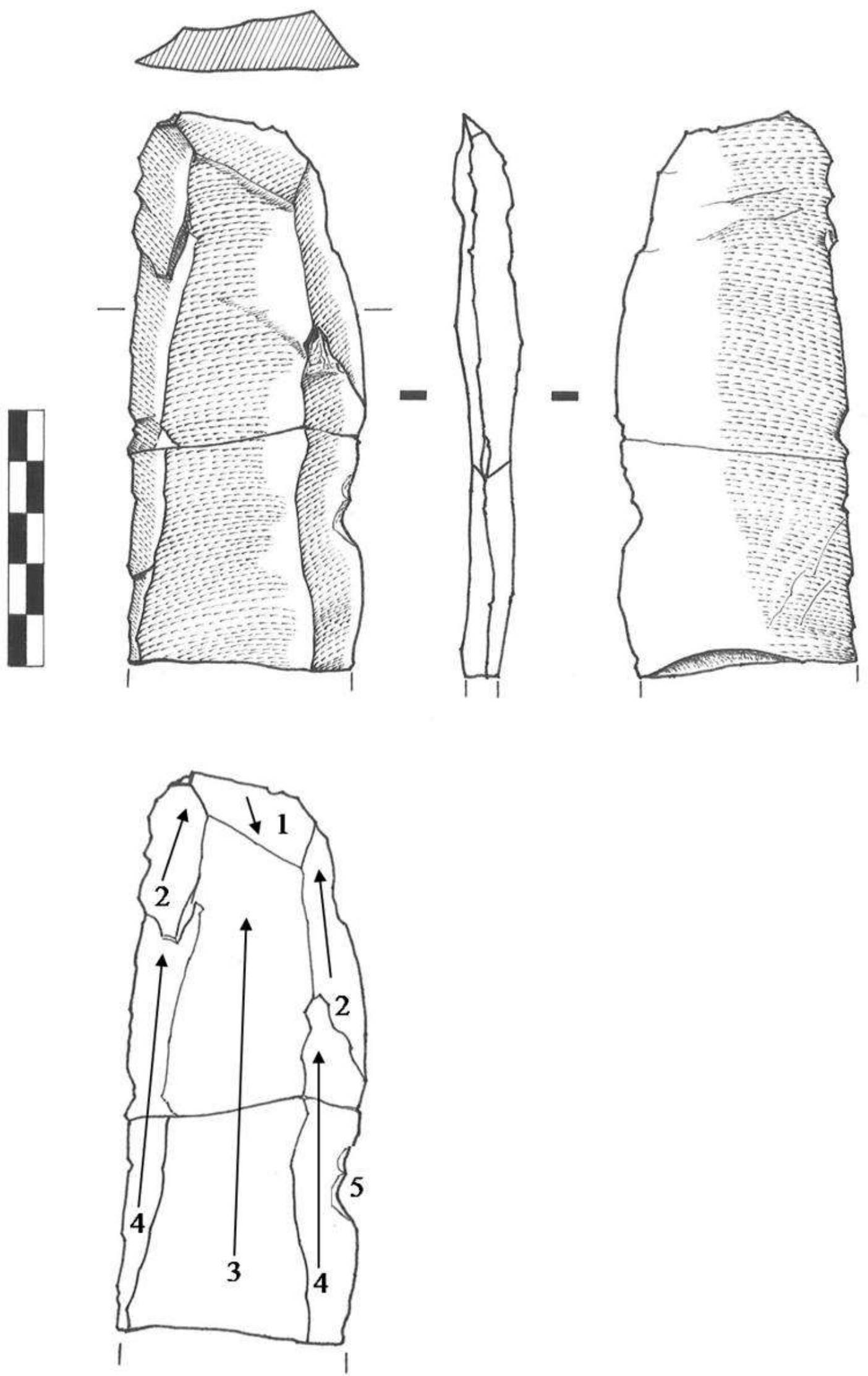

Figure 4. Technological drawing (superior) and diacritic scheme (inferior) of blade resulting from refitting fragments PCO024-a (top fragment) and PCO024-b (bottom fragment). Arrows indicate interpreted direction of the flaking and numbers indicate the order of removal. 


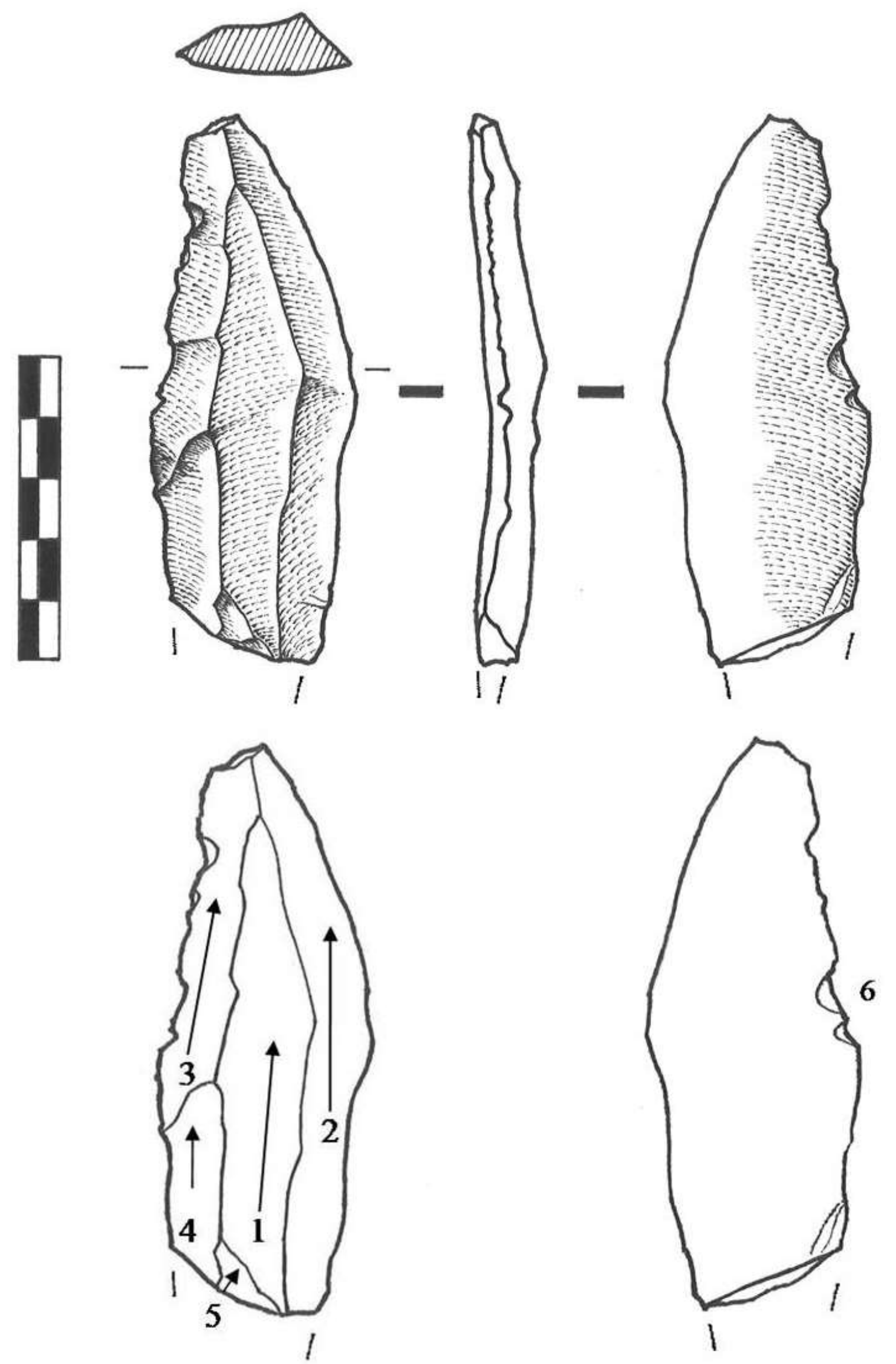

Figure 5. Technological drawing (superior) and diacritic scheme (inferior) of blade PCO023. Arrows indicate interpreted direction of flaking and numbers indicate the order of removal. 

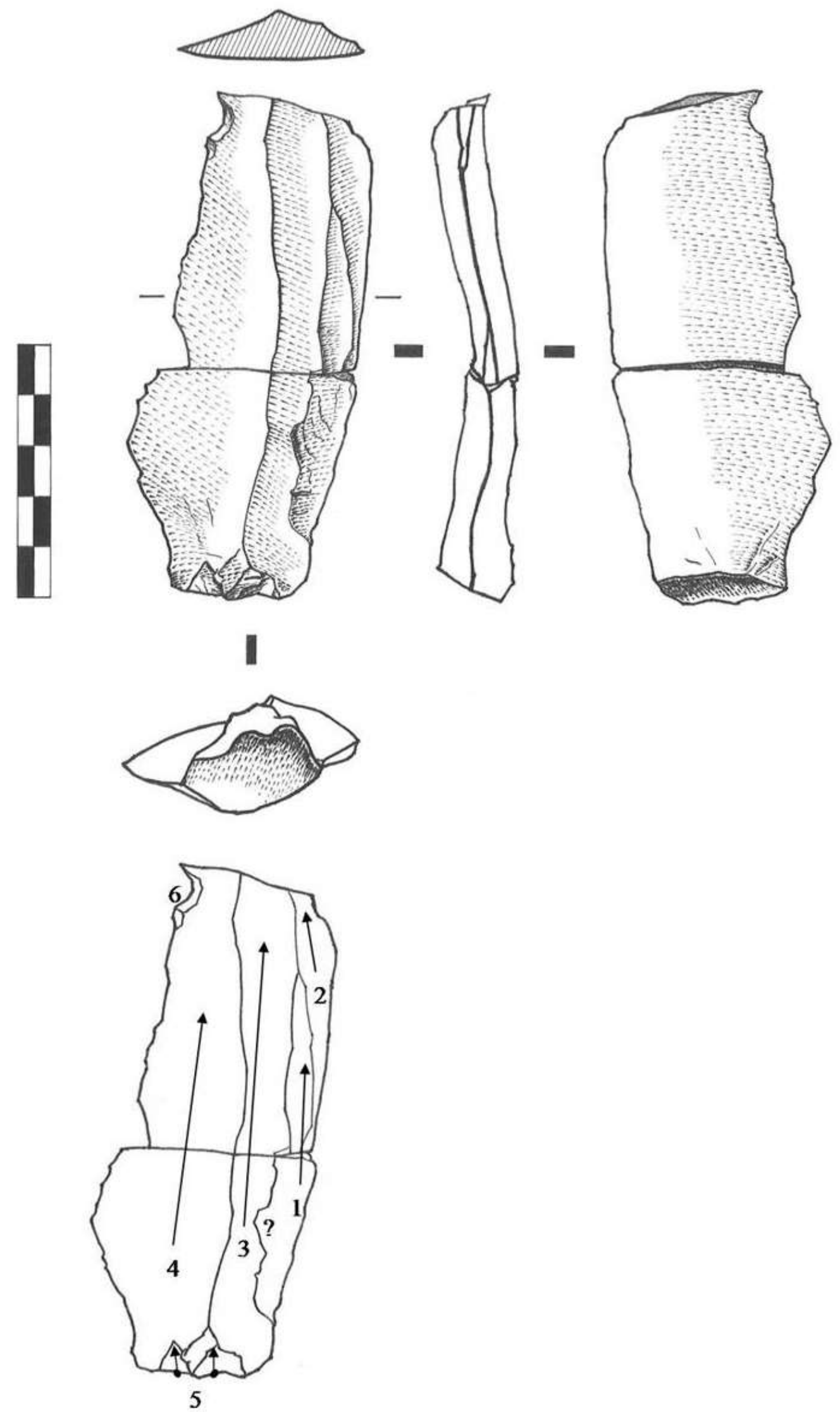

Figure 6. Technological drawing (superior) and diacritic scheme (inferior) of blade refitted with broken blade PCO025-a (bottom fragment) and blade fragment PCO025-b (top fragment). Arrows indicate interpreted direction of the flaking and numbers indicate the order of removal. 


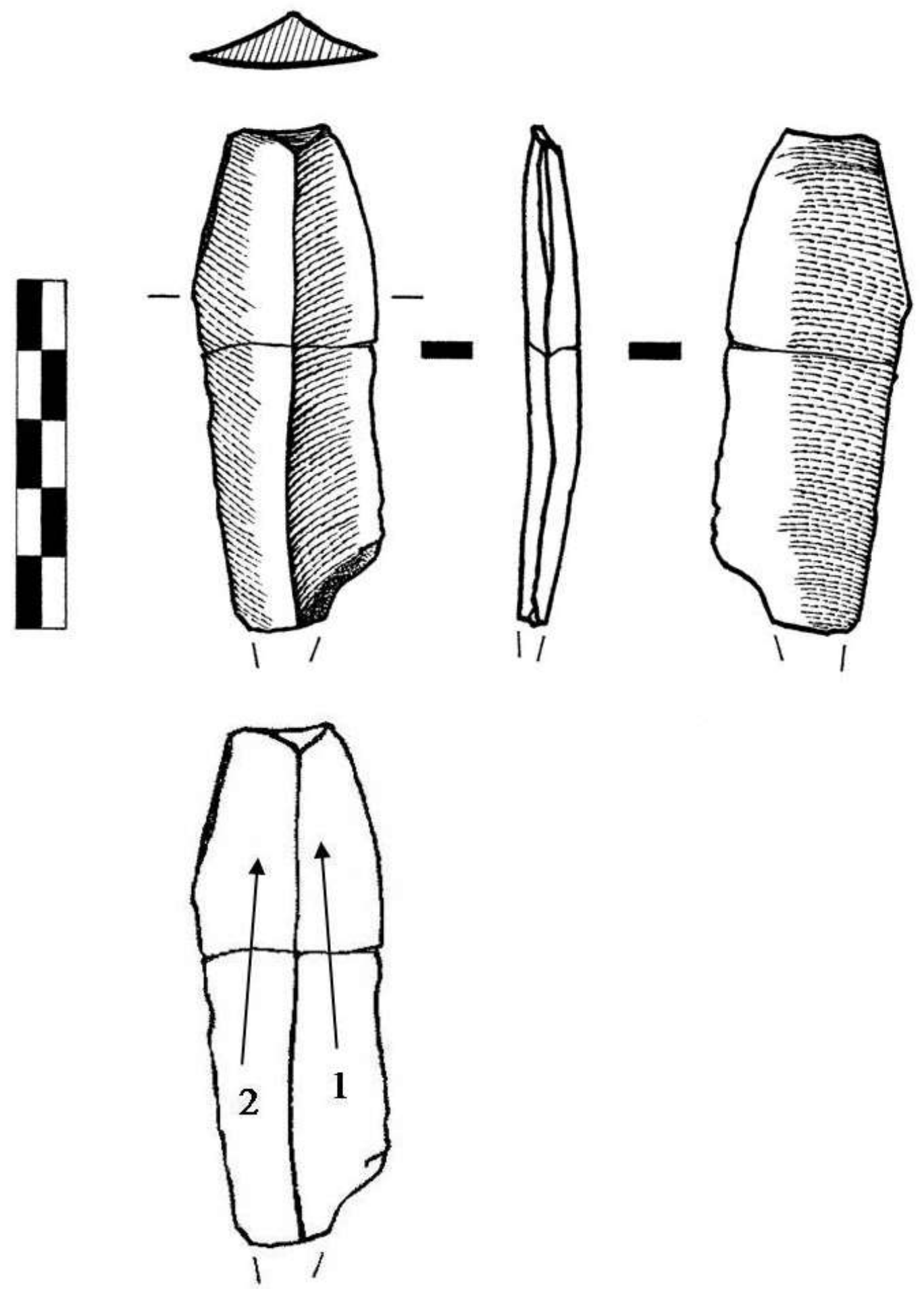

Figure 7. Technological drawing (superior) and diacritic scheme (inferior) of blade resulting from refitting fragments PCO026-a (bottom fragment) and PCO026-b (top fragment). Arrows indicate interpreted direction of the flaking and numbers indicate the order of removal.

The artifact PCO023 (Figure 5) is made on a fine-grained reddish brown (5YR 5/3) silicified sandstone. It presents a diffuse bulb. It is a double-ridged blade fragment in which a first extraction in the central part was followed by 2 sub-parallel removals. These scars correspond to what Lourdeau et al. (2014: 193) termed "the production phase", i.e., the obtainment of blades and blade blanks from the core. Two further detachments were made in which the negative of the bulb was preserved, and that would correspond to the preparation of 
the point of impact prior to the extraction of the blade. Finally, two marginal retouch removals were made on the mid-point of the ventral face, using a striking angle of $55^{\circ}$.

Artifact PCO024 (Figure 4), resulting from refitted fragments PCO024-a (Figure 4, top fragment) and PCO024-b (Figure 4, bottom fragment) is made from a fine-grained dark reddish gray (5YR 4/2) silicified sandstone. It also has two main ridges but seems to exhibit a more complex history. A first extraction is evidenced at the proximal end that is possibly related to the initiation phase of the core (i.e., the preparation of the blade core, see Lourdeau et al. 2014: 193-194). Afterwards, two removals were made which partially erased the first extraction scar, possibly related to the production of other blades. The next scar points to the production of a blade in the central part of the artifact, just like in the artifact presented before, that was followed up by two extractions on both sides.

Two marginal micro-retouch extractions were made at a blow angle of $76^{\circ}$ in the dorsal face, below the preserved mid-point of the artifact.

The artifact refitted with broken blade PCO025-a (Figure 6, bottom fragment) and blade fragment PCO025-b (Figure 6, top fragment) is made on a fine-grained reddish brown (5YR $5 / 3$ ) silicified sandstone. It presents a flat platform (26.00 mm wide x $15.00 \mathrm{~mm}$ deep) with evidence of abrasion and a prominent bulb. It exhibits three ridges from the production of previous blades. A first extraction is preserved on the right side, which also shows scars of a small removal of material (Figure 6, question mark in diacritic scheme) possibly caused by weathering or recent damage caused by human activity. A second removal adjacent to the first was made on the right side, which was followed by two other parallel extractions towards the center and left side of the artifact. Small flakes were then detached from the blade platform, possibly as part of the preparation of the point of impact used to extract the blade. Finally, retouch scars are present in the superior left side of the dorsal face, with an angle of $73^{\circ}$.

Artifact PCO026 (Figure 7), resulting from refitted fragments PCO026-a (Figure 7, bottom fragment) and PCO024-b (Figure 7, top fragment) is made from a fine-grained reddish brown (5YR 5/3) silicified sandstone. It exhibits one ridge along the longitudinal center of the blade separating two previous parallel blade extractions (Figure 7, diacritic scheme).

\section{Discussion and conclusions}

The Picão site in São Paulo state offers a new record of blades in Brazil, with several implications for lithic studies in South America. Firstly, the archaeological periods of blade production in the geographically-closest, dated contexts of southern Brazil ( 730 linear km away) and northern Uruguay ( 1,280 linear km away) encompass the Late Pleistocene to Early Holocene transition and the Early Holocene (Hoeltz et al. 2015; Lourdeau et al. 2014; Suárez 2011a, 2011b; Suárez et al. 2017 in press). Although no dates were yet obtained for the Picão site, some of the dates for lithic assemblages from the neighbouring Bastos site (Araujo \& Correa 2016) fall within this same temporal range. Future excavations at Picão should be able to shed light on the chronology of blade production in central São Paulo state.

Secondly, the blades reported here exhibit some similarities and differences with those recovered in southern Brazil and northern Uruguay. In terms of size, the complete blade is $93.0 \mathrm{~mm}$-long, with a fractured artifact that is at least $112.5 \mathrm{~mm}$-long. This makes them within the range of measurements for the southern Brazilian blades (between 30.0 and 149.0 mm-long) (Lourdeau et al. 2014: fig. 6) and blade core negatives (60.0 to $100.0 \mathrm{~mm}$-long) (Lourdeau et al. 2017: 5-11). The Picão blades, with the exception of refitted fragments PCO026-a and PCO026-b which suggest a blade at least $70.50 \mathrm{~mm}$-long, are slightly longer than those recovered in dated contexts in northern Uruguay, which are between 36.40 and $75.62 \mathrm{~mm}$-long in the Pay Paso 1 site (Suárez 2011a: table 6.4) and up to $50.0 \mathrm{~mm}$ long in the 
Tigre site (Suárez et al. 2017 in press: fig. 9). However, blades longer than $113.0 \mathrm{~mm}$ were reported from surface scatters in Uruguay (Suárez 2015: fig. 5).

The longitudinal curvature of the Picão site blades (Table 1) is less than that observed among Uruguayan artifacts, which are between 4.20 and 5.00 (Suárez 2011b: table 4). This morphological aspect is possibly a result of holding and rotating the core during knapping (Boldurian \& Hoffman 2009: 183), and is thought to have been a procured attribute of Clovis blades and blade tools (average curvature $=9.00$ ) (Bradley et al. 2010: 53).

In spite of the absence of cores at the Picão site, some generalizations about blade production can be made that allow comparisons with the two mentioned areas. The initiation of the core by means of centripetal extractions around the flaking surface, common among the southern blades (Lourdeau et al. 2014; 2017), could not be detected here, although the potential use of this method cannot be discarded based on the few specimens found at the Picão site. All of the blades present unidirectional parallel scars related to previous blade extractions detached from a single striking platform, which is a characteristic of the blades reported by Lourdeau et al. (2014) and is also evidenced in the cores collected in the same area (Lourdeau et al. 2017). This production method is also evidenced in the northern Uruguay blades and blade cores (Suárez 2011b: 367-370, fig. 7). The preparation of the striking point prior to blade extraction, recorded by Lourdeau et al. (2014) and Suárez (2011a: 128-130), is also present in the Picão artifacts.

Another important similarity resides in the evidence of use via micro-retouch and retouch along the lateral edges of the blades. Lateral working edges were detected among the blades from southern Brazil, with cases of distal retouch being rare (Lourdeau et al. 2014: 198), as seems to have been the case in northern Uruguay (Suárez 2011b). The possible uses of the Picão site blades cannot be determined without microscopic use-wear analysis. Diversity rather than uniformity seems to characterize South American blade functions, as indicated by use-wear and starch grain analysis (Dillehay \& Bonavia 2017; Grobman et al. 2012; Lynch \& Hermo 2017).

Finally, the absence of chronological data inhibits further interpretations about cultural relationships and affiliations of the blades under study. As blades were produced in different periods in South America, they are not culturally diagnostic artifacts per se. Similarities and differences reported here with blades from nearby contexts have stimulated the need for more research at Picão and other sites that can bring new insights into the origins and circulation of this technology in southeastern South America.

\section{Acknowledgements}

The archaeological survey was carried out while N. B. was receiving a CAPES (Coordination of Superior Personnel Improvement of Brazil) grant. Current research in the Dourado Municipality is being developed with the financial support of FAPESP - São Paulo State Research Foundation (Research Grant 2016/23584-6). Thanks to Jennifer Watling for correction of the English and Glauco C. Perez for making the map in Figure 1. Thanks to two anonymous reviewers for suggestions to improve the paper. Authors especially thank Mr.

Moacyr P. Toledo Jr., Mr. Ricardo A. Bastos and Mrs. Maria Helena Monteiro Bastos for the logistic support for this research.

\section{References}

Adovasio, J. \& Pedler, D. R. 2004, Pre-Clovis sites and their implications for human occupation before the Last Glacial Maximum. In: Entering America. Northeast Asia and 
Beringia before the Last Glacial Maximum (Madsen, D. B., Ed.), The University of Utah Press, Salt Lake City: p. 139-158.

Araujo, A. G. M. 2001a, A arqueologia da região de Rio Claro: Uma síntese. Revista do Museu de Arqueologia e Etnologia, 11: 125-140. (in Portuguese) ("Archaeology of the Rio Claro region: A synthesis”) doi:10.11606/issn.2448-1750.revmae.2001.109414

Araujo, A. G. M. 2001b, Destruído pelo arado? Arqueologia de superfície e as armadilhas do senso comum. Revista de Arqueologia, 14-15: 7-28. (in Portuguese) ("Destroyed by plowing? Surface archaeology and the common-sense traps") doi:10.24885/Sab.v14i1.162

Araujo, A. G. M. \& Correa, L. 2016, First notice of a Paleoindian site in central São Paulo State, Brazil: Bastos site, Dourado County. Paleoindian Archaeology, 1(1): 04-14. URL: http://journals.kvasirpublishing.com/pa/article/view/17/56

Araujo, A. G. M., Paisani, J. C., Schrage, T. J., Feathers, J. K., Hartmann, G. A. \& Ricci, O. 2017, The "Lagoa do Camargo 1" Paleoindian site: Some implications for tropical geomorphology, pedology, and paleoenvironments in southeastern Brazil.

Geoarchaeology: An International Journal, 32(6): 662-677. doi:10.1002/gea.21628

Aschero, C. A., Bellelli, C. \& Goñi, R. A. 1993, Avances en las investigaciones arqueológicas del Parque Nacional Perito Moreno (Provincia de Santa Cruz, Patagonia Argentina). Cuadernos del Instituto Nacional de Antropología y Pensamiento Latinoamericano, 14: 143-170. (in Spanish) (“Advances in the archaeological research at Perito Moreno National Park (Santa Cruz Province, Argentinean Patagonia)")

Bar-Yosef, O. \& Kuhn, S. L. 1999, The big deal about blades: Laminar technologies and Human Evolution. American Anthropologist, 101(2): 322-338. doi:10.1525/aa.1999.101.2.322

Beck, C. \& Jones, G. T. 2015, A case of extinction in Paleoindian archaeology. In: Lithic technological systems and evolutionary theory (Goodale, N. \& Andrefsky, W., Eds.), Cambridge University Press, New York: p. 83-99.

Beltrão, M. C. M. 1974, Datações arqueológicas mais antigas do Brasil. Anais da Academia Brasileira de Ciências, 46(2): 211-251. (in Portuguese) ("Earliest archaeological dates in Brazil")

Boëda, E. 1988, Le concept laminaire: Rupture et filiation avec le concept Levallois. In: La mutation (Kozlowski, J. K., Ed.), L’Homme de Néandertal: Actes du Colloque International de Liège, Vol. 8. Université de Liège and Societé Belge d'Anthropologie et de Préhistoire, Liège: p. 41-59. (in French) ("The laminar concept: Rupture and filiation with the Levallois concept")

Boldurian, A. T. \& Hoffman, E. E. 2009, Clovis blade manufacture: Analytical procedure to infer 'technique'. North American Archaeologist, 30(2): 167-194. doi:10.2190/NA.30.2.d

Bradley, B. A., Collins, M. B. \& Hemmings, A. 2010, Clovis technology. Archaeological Series Vol. 17, International Monographs in Prehistory, Ann Arbor, 220 p.

Cardich, A., Cardich, L. \& Hadjuk, A. 1973, Secuencia arqueológica y cronología radiocarbónica de la Cueva 3 de Los Toldos (Santa Cruz, Argentina). Relaciones de la Sociedad Argentina de Antropología, 7: 87-122. (in Spanish) (“Archaeological sequence and radiocarbon chronology of Los Toldos, Cueva 3 site (Santa Cruz, Argentina)") 
Collins, M. B. 1999, Clovis blade technology: A comparative study of the Keven Davis Cache, Texas. University of Texas Press, Austin, 203 p.

Collins, M. B. \& Lohse, J. C. 2004, The nature of Clovis blades and blade cores. In: Entering America. Northeast Asia and Beringia before the Last Glacial Maximum (Madsen, D. B., Ed.), The University of Utah Press, Salt Lake City: p.159-183.

Dauvois, M. 1976, Précis de dessin dynamique et structural des industries lithiques préhistoriques. Pierre Fanlac, Périgueux, 263 p. (in French) ("A guide to dynamic and structural drawing of prehistoric lithic industries")

Dillehay, T. D. \& Bonavia, D. 2017, Nontextile and nonbasketry material culture. In: Where the land meets the sea: Fourteen millennia of human history at Huaca Prieta, Peru (Dillehay, T. D., Ed.), University of Texas Press, Austin: p. 434-457.

Grobman A., Bonavia, D., Dillehay, T. D., Piperno, D. R., Iriarte, J. \& Holst, I. 2012, Preceramic maize from Paredones and Huaca Prieta, Peru. Proceedings of the National Academy of Sciences, 109(5): 1755-1759. doi:10.1073/pnas.1120270109

Hermo, D. \& Lynch, V. 2015, Core technology from Maripe Cave site (Santa Cruz, Argentina): Implications for rock provisioning processes and lithic production. Quaternary International, 375: 135-144. doi:10.1016/j.quaint.2014.11.063

Hermo, D. \& Magnin, L. 2012, Blade and bifacial technology in mid-Holocene occupations at Deseado Massif, Santa Cruz Province, Argentina. Quaternary International, 256: 7177. doi:10.1016/j.quaint.2011.09.034

Hilbert, K. 1991, Aspectos de la arqueología en el Uruguay. Verlag Philipp von Zabern, Mainz am Rhein, 193 p. (in Spanish) (“Aspects of archaeology in Uruguay”)

Hirth, K. G. 2012, The organizational structures of Mesoamerican obsidian prismatic blade technology. In: The emergence of pressure blade making: From origin to modern experimentation (Desrosiers, P. M., Ed.), Springer Science-Business Media, New York: p. 401-415. doi:10.1007/978-1-4614-2003-3_16

Hoeltz, S. E., Lourdeau, A. \& Viana, S. 2015, Um novo conceito de lascamento no sul do Brasil: Debitagem laminar na foz do rio Chapecó (SC/RS). Revista do Museu de Arqueologia e Etnologia, 25: 3-19. (in Portuguese) ("A new flaking concept in southern Brazil: Blade debitage in the mouth of Chapecó river (Santa Catarina/Rio Grande do Sul)"). doi:10.11606/issn.2448-1750.revmae.2015.114852

Inizan, M.L., Reduron-Ballinger, M., Roche, H. \& Tixier, J. 1995, Technologie de la pierre taillée. Préhistoire de la pierre taillée Vol. 4. Cercle de Recherches et d'Études Préhistoriques, Meudon, 199 p. (in French) ("Technology of knapped stone")

Instituto de Pesquisas Tecnológicas do Estado de São Paulo (IPT) 1981, Mapa Geomorfológico do Estado de São Paulo. Nota Explicativa. Vol. 1, Secretaria da Indústria, Comércio, Ciência e Tecnologia, Governo do Estado de São Paulo, São Paulo, 94 p. (in Portuguese) ("Geomorphological map of São Paulo State. Explanatory note")

Lewarch, D. E. \& O'Brien, M. J. 1981, The expanding role of surface assemblages in archaeological research. In: Advances in archaeological method and theory, Vol. 4 (Schiffer, M. B., Ed.), Springer, New York: p. 297-342.

URL: http://www.jstor.org/stable/20170170 
Lopes, R. C., Peruffo, N., Sachs, L. L. B., Silva, V. A. \& Batista, I. H. 2004, Folha SF 22, Paranapanema. In: Carta Geológica do Brasil ao Milionésimo. Sistema de Informações Geográficas (Schobbenhaus, C., Gonçalves, J. H., Santos, J. O. S., Abram, M. B., Neto, R. L., Matos, G. M. M., Vidotti, R. M., Ramos, M. A. B. \& Jesus, J. D. A., Eds.), Programa Geologia do Brasil, CPRM, Brasília: p. 22-22. (in Portuguese) ("Sheet SF 22, Paranapanema")

Lourdeau, A., Carbonera, M., Hoeltz, S., Santos, M. C. P., Oliveira e Lucas, L., Costa, A. \& Viana, S. A. 2017, Debitagem laminar no Sul do Brasil: Habemus nucleos! Journal of Lithic Studies, 4(3): 17 p. (in Portuguese) ("Blade debitage in southern Brazil: We have cores!") doi:10.2218/jls.v4i3.2530

Lourdeau, A., Hoeltz, S. \& Viana, S. A. 2014, Early Holocene blade technology in southern Brazil. Journal of Anthropological Archaeology, 35: 190-201. doi:10.1016/j.jaa.2014.06.003

Lynch, V. \& Hermo, D. 2017, De la producción al uso: Tecnología de hojas en el sitio Cueva Maripe (Santa Cruz, Argentina). Chungara, Revista de Antropología Chilena, 49(2): 193-208. (in Spanish) ("From production to use: Blade technology at Cueva Maripe site (Santa Cruz, Argentina)") doi:10.4067/S0717-73562017005000010

Menghin, O.1952, Fundamentos cronológicos de la Prehistoria de Patagonia. Runa, 5: 23-43. (in Spanish) ("Chronological basis of the prehistory of Patagonia")

Nami, H. G. 2013, Archaelogy, Paleoindian research and lithic technology in the Middle Negro river, central Uruguay. Archaeological Discovery, 1: 1-22. doi:10.4236/ad.2013.11001

Nami, H. G. \& Bellelli, C. 1994, Hojas, experimentos y análisis de desechos de talla. Implicaciones arqueológicas para la Patagonia centro-septentrional. Cuadernos del Instituto Nacional de Antropología y Pensamiento Latinoamericano, 15: 199-223. (in Spanish) ("Blades, experiments and debitage analysis. Archaeological implications for central-northern Patagonia”)

Paunero, R. S. 2003, The Cerro Tres Tetas (C3T) locality in the Central Plateau of Santa Cruz, Argentina. In: Where the south winds blow: Ancient evidence of Paleo South Americans (Miotti, L., Salemme, M. C., Flegenheimer, N. \& Bonnichsen, R., Eds.), Center for the Study of the First Americans and Texas A \& M University Press, College Station: p. 133-140.

Restifo, F. 2015, Tecnología de hojas líticas en tierras altas andinas: Perspectivas desde la puna de la Provincia de Salta (Argentina). Estudios Atacameños, 51: 33-51. (in Spanish) ("Lithic blade technology in the Andean highlands: Perspectives from the Salta Province arid plateau (Argentine)") doi:10.4067/S0718-10432015000200004

Restifo, F. \& Hoguin, R. 2012, Risk and technological decision-making during the Early to mid-Holocene transition: A comparative perspective in the Argentine puna. Quaternary International, 256: 35-44. doi:10.1016/j.quaint.2011.10.030

Sain, D. A. 2012, Clovis blade technology at the Topper Site (38AL23): Assessing lithic attribute variation and regional patterns of technological organization. Occasional Papers Vol. 2, Southeastern Paleoamerican Survey, University of South Carolina, Columbia, 226 p. URL:

http://scholarcommons.sc.edu/archanth_occasional_paleoam_papers/2 
Santos, F. G. 2011, Sítios líticos no interior paulista: Um enfoque regional. Master thesis at the Museu de Arqueologia e Etnologia, Universidade de São Paulo, São Paulo, 181 p. (in Portuguese) ("Lithic sites in the Paulistan interior: A regional approach") doi:10.11606/D.71.2011.tde-01112011-092458

Skarbun, F., Frank, A. D., Cueto, M. E., Paunero, M. F. \& Rosales, G. 2007, Análisis de la tecnología lítica del sitio Casa del Minero 1, Meseta Central de Santa Cruz. In: Arqueología de Fuego-Patagonia: Levantando piedras, desenterrando huesos ...y develando arcanos (Morello, F., Prieto, A., Martinic, M. \& Bahamondes, G., Eds.), Centro de Estudios del Cuaternario Antártico, Punta Arenas: p. 589-600. (in Spanish) ("Lithic technology analysis of Casa del Minero 1 site, Central Plateau of Santa Cruz")

Suárez, R. 2011a, Arqueología durante la transición Pleistoceno-Holoceno en Uruguay: Componentes Paleoindios, organización de la tecnología lítica y movilidad de los Primeros Americanos. BAR International Series Vol. 2220. Archaeopress, Oxford, 254 p. (in Spanish) ("Archaeology during Pleistocene-Holocene transition in Uruguay: Paleoindian components, lithic technological organization and mobility of the first Americans")

Suárez, R. 2011b, Movilidad, acceso y uso de ágata traslúcida por los cazadores-recolectores tempranos durante la transición Pleistoceno-Holoceno en el Norte de Uruguay (ca. 11,000-8,500 a.P). Latin American Antiquity, 22(3): 359-383. (in Spanish) ("Mobility, accessibility and use of translucent agate by early hunter-gatherers during the Pleistocene-Holocene transition in northern Uruguay (ca. 11,000-8,500 BP)"). URL: http://www.jstor.org/stable/23072527

Suárez, R. 2015, The Paleoamerican occupation of the plains of Uruguay: Technology, adaptations, and mobility. PaleoAmerica, 1(1): 88-104. doi:10.1179/2055556314Z.00000000010

Suárez, R., Piñeiro, G. \& Barceló, F. in press, Living on the river edge: The Tigre site (K-87) new data and implications for the initial colonization of the Uruguay river basin. Quaternary International, 20 p. (Accepted for publication $8^{\text {th }}$ august 2017). doi:10.1016/j.quaint.2017.08.024

Suárez, R., Vegh, J. \& Astiazarán, J. 2018, Fishtail points, blades, and preforms and the Paleoamerican occupation of the Yí River (Uruguay): New evidence from La Palomita. PaleoAmerica, 4(1): 87-89. doi:10.1080/20555563.2017.1415651

Taddei, A. 1980, Un yacimiento de cazadores superiores en el Río Negro (Paso del Puerto) (Uruguay). In: Actas del III Congreso Nacional de Arqueología, IV Encuentro de Arqueología del Litoral (Centro de Estudios Arqueológicos, Ed.), Centro de Estudios Arqueológicos, Montevideo: p. 21-64. (in Spanish) (“A superior hunters' site in the Negro river (Paso del Puerto) (Uruguay)")

Troncoso, L. P. S., Corrêa, A. A. \& Zanettini, P. E. 2016, Paleoíndios em São Paulo: Nota ao respeito do sítio Caetetuba, Município de São Manuel, SP. Paleoindian Archaeology, 1(1): 50-71. (in Portuguese) ("Paleoindians in São Paulo: Note on the Caetetuba site, São Manuel Municipality, SP”).

URL: http://journals.kvasirpublishing.com/pa/article/view/14/24

Waters, M. R. \& Stafford Jr., T. W. 2007, Redefining the age of Clovis: Implications for the peopling of the Americas. Science, 315: 1122-1126. doi:10.1126/science.1137166 